\title{
CHEMICAL FEATURES OF SPORE COAT OF BACILLUS SUBTILIS
}

\author{
TAKAHIKO MITANI AND HAJIME KADOTA \\ Laboratory of Microbiology, Department of Fisheries, Faculty \\ of Agriculture, Kyoto University, Kyoto, Japan
}

(Received August 19, 1975)

\begin{abstract}
The spore coat of Bacillus subtilis was isolated and solubilized by treatment with sodium dodecyl sulfate (SDS) plus dithiothreitol (DTT) solution. This treatment solubilized about $85 \%$ of the spore coat fraction and the soluble fraction mainly consisted of protein. The protein was purified in a buffer containing the detergent. The results of gel filtration, SDSdisc gel electrophoresis and $\mathrm{NH}_{2}$-terminal analysis showed the major component of the spore coat protein to be one kind with a molecular weight of 14,000 .
\end{abstract}

It is well known that the spore coat of bacilli consists mainly of protein. However, chemical and physical properties of spore coat protein have not been clearly elucidated. Since the spore coat protein is highly hydrophobic it is very difficult to solubilize it with a diluted aqueous salt solution $(1,2)$. Attempts have been made with a number of bacterial species to solubilize the spore coat protein. Aronson and Fitz-James have reported that about $80 \%$ of spore coat of Bacillus subtilis $\mathrm{T}$ was solubilized by the treatment with dithioerythritol (DTE) plus sodium dodecyl sulfate (SDS) (3). LECADET et al. (4) found with $B$. thuringiensis that the spore coat protein solubilized with $10 \% \beta$-mercaptoethanol plus $8 \mathrm{M}$ urea consisted of several kinds of proteins. SOMERville et al. (5) reported that, by the treatment with urea and $\beta$-mercaptoethanol, spores of $B$. thuringiensis were partially solubilized to give a protein fraction which showed a single band in a disc electrophoresis. Recently, ARONSON and HORN (6) showed that the soluble fraction obtained from the whole spore of $B$. cereus $\mathrm{T}$ was composed of one or two kinds of polypeptides. In most of these works, however, the solubilization percentages were generally low and chemical features of the coat proteins were still obscure.

In the present work we attempted to solubilize the isolated spore coat of $B$. subtilis by the use of SDS, to purify it by treatment with various buffer solutions 
and detergents, and to characterize chemically the solubilized fraction obtained from the spore coat.

\section{MATERIALS AND METHODS}

Bacterial strains and media. Bacillus subtilis ATCC 6051 (Marburg) was grown at $37^{\circ}$ in a nutrient broth medium which was prepared to contain $5 \mathrm{~g}$ of beef extract and $5 \mathrm{~g}$ of Polypepton in $1,000 \mathrm{ml}$ of potato extract $(300 \mathrm{~g}$ of potato extracted with $1,000 \mathrm{ml}$ of water) (7). The final $\mathrm{pH}$ was adjusted to 7.2. The inoculated medium was incubated for $72 \mathrm{hr}$ in a jar fermentor. After incubation the cells were harvested by centrifugation at $10,000 \times g$ and washed several times with deionized water.

Purification of spores. Spores were freed of vegetative cells using the twophase Y system of SACKs and Alderton (8). The spores were then purified by further washing with deionized water and lyophilized. By these treatments more than $97 \%$ of the spores obtained were refractile.

Preparation and solubilization of spore coat. The cleaned spores were disrupted in a Braun disintegrater. The disrupted spores were centrifuged at $10,000 \times g$ for $15 \mathrm{~min}$, and the sediment obtained was resuspended in $\mathrm{m} / 15$ phosphate buffer of $\mathrm{pH}$ 7.0. The spore coat fraction was further treated with lysozyme in order to remove debris of contaminating vegetative cells. After lysozyme treatment the spore coat fraction was subsequently washed several times with water and then lyophilized.

Spore coat protein was extracted from the purified spore coat fraction with either $1 \%$ SDS in the presence of $0.1 \mathrm{M}$ dithiothreitol (DTT) in $0.1 \mathrm{M}$ sodium borate buffer ( $\mathrm{pH} 10.0$ ) or $0.08 \mathrm{~N} \mathrm{NaOH}$. The former was designated "SD fraction" and the latter, "SN fraction". The extraction was made at $50^{\circ}$ for $30 \mathrm{~min}$. After the fractions were centrifuged the supernatant obtained was dialyzed against deionized water and lyophilized.

Sephadex G-200 gel filtration. The molecular weight of each spore coat fraction was determined by chromatography in a column $(75 \times 2.2 \mathrm{~cm})$ of Sephadex G-200 equilibrated with $0.1 \%$ SDS in 0.05 m sodium borate buffer ( $\mathrm{pH} 10.0$ or 12.0) or in $0.05 \mathrm{M}$ Tris-HCl buffer ( $\mathrm{pH} 8.0$ ). Blue Dextran 2000 (Pharmacia) was used to measure void volume of the column, $\mathrm{V}_{0}$. Ovalbumin (molecular weight: 45,000), whale sperm myoglobin (molecular weight: 17,800), bovine serum albumin (molecular weight: 67,000), and human $\gamma$-globulin (molecular weight: 12,400) which were purchased from Schwart-Mann or Sigma were used as the molecular weight standards. The molecular weight was estimated from a plot of logarithm of molecular weight against elution volume. The column fractions were assayed for protein by a turbidimetric procedure similar to that reported by FisH et al. (9).

SDS polyacrylamide gel electrophoresis. One milligram each of SD and SN fraction from the spore coat was dissolved in $1 \mathrm{ml}$ of a solution which contained $0.2 \%$ SDS and $5 \% \beta$-mercaptoethanol in $0.1 \mathrm{M}$ sodium borate buffer $(\mathrm{pH} \mathrm{12.0})$ 
and incubated at $37^{\circ}$ for $30 \mathrm{~min}$. A $10 \%$ polyacrylamide gel containing $0.1 \%$ SDS and $0.05 \mathrm{M}$ sodium borate buffer ( $\mathrm{pH} 10.0$ and 12.0) was used for the electrophoresis after the procedure of WEBER and OSBORN (10). The gel was subsequently stained with Amido Black. Several different polypeptides were used as molecular weight markers.

Sedimentation velocity studies. Sedimentation velocities were estimated by the use of a Spinco $E$ analytical ultracentrifuge equipped with a phase plate Schlieren diagram. Fringe displacement measurements were made with a Nikon optical microcomparator.

Amino acid analysis. The amino acid composition of each of the spore coat fractions was determined with a Hitachi autoanalyser according to SPACKMAN et al. (11). Five milligrams of the sample was added to $1 \mathrm{ml}$ of $6 \mathrm{~N} \mathrm{HCl}$ in a glass tube sealed, and heated at $110^{\circ}$ for $24 \mathrm{hr}$. After removal of $\mathrm{HCl}$ by evaporation in a vacuum desiccator, the residue was solubilized with $5 \mathrm{ml}$ of $0.02 \mathrm{M}$ citrate buffer ( $\mathrm{pH}$ 2.2). The hydrolysates obtained were assayed for amino acids.

Identification of $\mathrm{NH}_{2}$-terminal amino acid. $\mathrm{NH}_{2}$-terminal amino acid was analyzed by Sanger's method. The reaction with 2-fluorodinitrobenzene was performed in $6 \mathrm{M}$ guanidine- $\mathrm{HCl}$ for $4 \mathrm{hr}$ at $40^{\circ}$ in the presence of $0.1 \mathrm{M}$ potassium bicarbonate (12). The reaction products were washed successively with cold $\mathrm{HCl}$, acetone, and ether. The dinitrophenylated protein was hydrolyzed with $6 \mathrm{~N} \mathrm{HCl}$ in an evacuated sealed tube for $16 \mathrm{hr}$ at $106^{\circ}$. After being washed with $0.1 \mathrm{~N} \mathrm{HCl}$, the extracts were dried and chromatographed over DC-Fertigplatten Kieselgel $\mathrm{F}_{254}$ (Merck), using the following solvent systems: (A) toluene-pyridine-ethylenechlorohydrin-0.8 $\mathrm{N} \mathrm{NH}_{4} \mathrm{OH}(100: 30: 60: 60, \mathrm{v} / \mathrm{v})$ and (B) chloroform-methanol-glacial acetic acid (95:5:1, v/v).

Elementary analysis was made at the laboratory for organic elemental microanalysis of Kyoto University. All the reagents used were the best commercially available.

\section{RESULTS}

\section{$S D$ fraction and $S N$ fraction}

The treatment of spore coat with SDS plus DTT solution and that with $\mathrm{NaOH}$ solution resulted in the solubilization of $85 \%$ and $60 \%$ in dry weight, respectively. The solubilized fractions obtained through these treatments were dialyzed against distilled water and then lyophilized. The lyophilized samples were suspended in

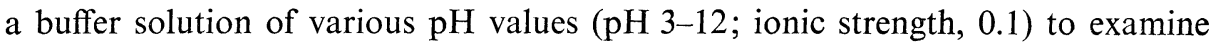
the effect of $\mathrm{pH}$ on the solubility. The solubility was estimated by measuring the optical density at $660 \mathrm{~nm}$. Figure 1 shows the $\mathrm{pH}$ vs. precipitation curves of these fractions. As shown in this graph, the solubilities of both SD and SN fractions were very high at $\mathrm{pH}$ values higher than 11 , respectively high at low $\mathrm{pH}$ values, and extremely low at pH 6 to 8 . When the buffer solutions contained SDS were employed the precipitation of protein hardly occurred at all $\mathrm{pH}$ values tested. The 


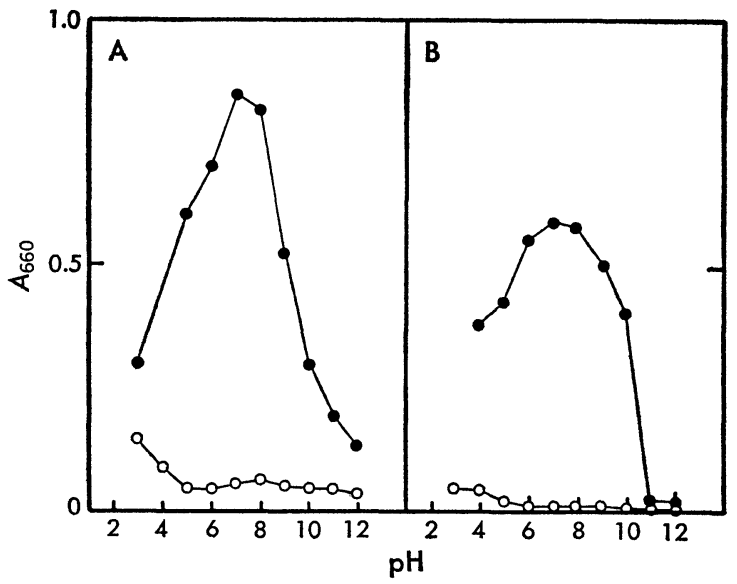

Fig. 1. Solubility of $\mathrm{SN}$ and $\mathrm{SD}$ fractions from spore coat of $B$. subtilis as a function of $\mathrm{pH}$ value.

precipitation and solubilization in these cases were reversible and $\mathrm{pH}$ dependent.

It was found from elementary analysis and amino acid analysis that these SD and SN fractions contained nitrogen in the concentration of approximately

Table 1. Amino acid composition of spore coat fractions from B. subtilis.

\begin{tabular}{lccccc}
\hline \multirow{2}{*}{ Amino acid } & \multicolumn{2}{c}{ Soluble fraction } & \multicolumn{2}{c}{ Insoluble fraction } & \multirow{2}{*}{$\begin{array}{c}\text { Spore } \\
\text { coat }\end{array}$} \\
\cline { 2 - 5 } & $\mathrm{NaOH}$ & $\mathrm{DTT}+\mathrm{SDS}$ & $\mathrm{NaOH}$ & $\mathrm{DTT}+\mathrm{SDS}$ & \\
\hline Lysine & 4.8 & 6.1 & 3.7 & 9.2 & 8.5 \\
Histidine & 2.1 & 2.0 & 2.3 & 3.4 & 3.8 \\
Arginine & 4.4 & 4.9 & 4.9 & 3.5 & 4.6 \\
Aspartic acid & 13.6 & 12.2 & 11.3 & 11.9 & 9.5 \\
Threonine & 5.1 & 5.0 & 5.6 & 5.0 & 4.8 \\
Serine & 7.2 & 7.3 & 7.5 & 9.2 & 7.1 \\
Glutamic acid & 8.3 & 6.8 & 6.8 & 8.8 & 7.7 \\
Proline & 3.7 & 3.6 & 3.1 & 3.8 & 4.1 \\
Glycine & 12.7 & 14.3 & 16.4 & 10.3 & 13.9 \\
Alanine & 8.5 & 8.7 & 9.2 & 7.7 & 7.1 \\
Cystine (half) & + & 0.8 & 0.3 & 0.8 & 2.2 \\
Valine & 5.5 & 5.2 & 5.5 & 5.7 & 4.9 \\
Methionine & 1.8 & 1.7 & 1.8 & + & 1.5 \\
Isoleucine & 4.6 & 4.3 & 4.5 & 3.5 & 3.7 \\
Leucine & 6.0 & 5.6 & 6.0 & 5.0 & 5.3 \\
Tyrosine & 7.4 & 7.1 & 6.5 & 8.4 & 6.8 \\
Phenylalanine & 4.2 & 4.6 & 6.5 & 3.8 & 5.0 \\
\hline
\end{tabular}

Values are $\mathrm{mol} \%$.

Tryptophan excluded; asparagine and glutamine were determined as aspartic acid and glutamic acid, respectively. 
$15 \%$, and that these fractions were composed of protein. Table 1 shows a comparison of amino acid compositions of the soluble and insoluble fractions obtained from spore coat of $B$. subtilis ATCC 6051. These results suggest that the spore coat protein of $B$. subtilis was characterized by a relatively high content of glycine as has been reported by other investigators for the spore coat of bacilli $(13,14)$. No striking difference in the amino acid composition was found between the soluble and insoluble fractions.

\section{SDS disc electrophoresis}

Electrophoretic patterns of SD and SN fractions from spore coat of $B$. subtilis and several kinds of authentic samples of proteins whose molecular weight is known are shown in Fig. 2. Based on these patterns electrophoretic mobilities of SD and $\mathrm{SN}$ fractions and marker proteins were plotted against logarithm of the molecular weight (Fig. 3), and a straight line relationship was found between the electro-

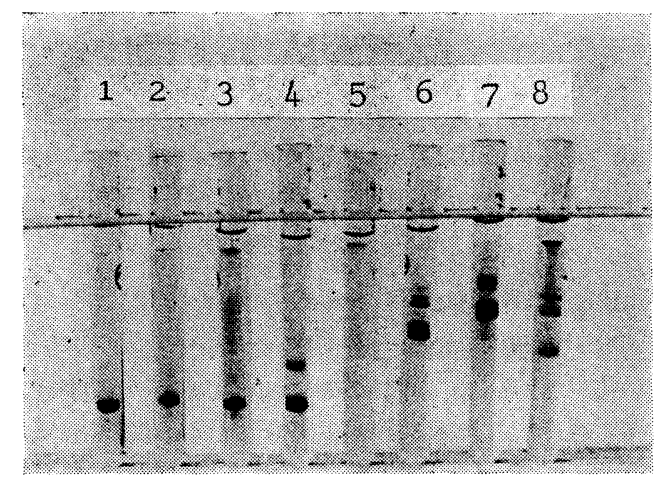

Fig. 2. Electrophoretic mobility of SD and SN fractions from spore coat and several kinds of authentic proteins in polyacrylamide gels containing SDS.

1 , cytochrome $c ; 2$, SD fraction; $3, \mathrm{SN}$ fraction; 4, myoglobin; 5 , chymotrypsinogen A; 6 , ovalbumin; 7 , albumin; $8, \gamma$-globulin.

phoretic mobility and the logarithm of molecular weight of proteins. From these results molecular weight of the solubilized protein from $B$. subtilis spore coat was calculated to be approximately 14,000. As shown in Fig. 2, SD fraction gave a distinct single band in the electrophoretic pattern. The $\mathrm{SN}$ fraction, however, gave several diffused bands, the principal one of which corresponded to the band found in the SD fraction. Such a behavior of SN fraction was also observed on the SDS gel filtration pattern as will be mentioned below.

\section{SDS gel filtration}

The SD fraction and authentic proteins were chromatographed with $0.05 \mathrm{M}$ sodium borate ( $\mathrm{pH} \mathrm{12.0)}$ ) on a Sephadex column in the presence of SDS (Fig. 4). Under these conditions, SD fraction gave a single peak with a shoulder. In the 


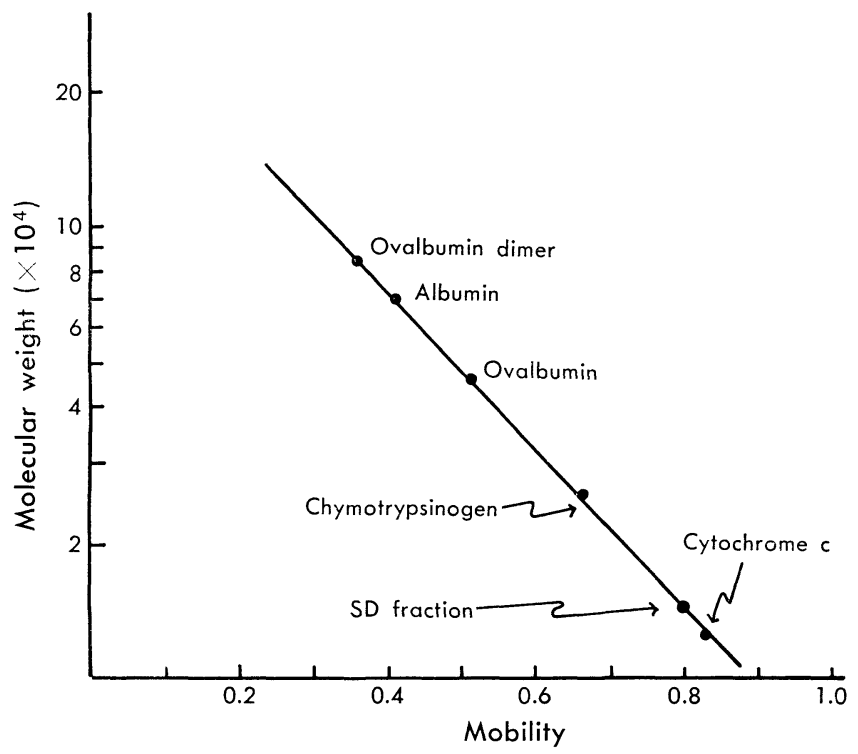

Fig. 3. Relationship between the logarithm of molecular weight and electrophoretic mobility of SD and SN fractions and several marker proteins.

elution profiles of SN fraction two peaks were found (Fig. 5). One of these two peaks corresponded to the peak found in the elution profiles of SD fraction. These results together with those of disc electrophoresis suggested that the spore coat protein solubilized by $0.08 \mathrm{~N} \mathrm{NaOH}$ was heterogeneous and contained some degradation products. When chromatography of SD fraction was performed at lower $\mathrm{pH}(\mathrm{pH} 8.0)$, another peak was found in the profile quite near the main peak (Fig. 6). It appeared that dissociation of the solubilized spore coat protein easily took place under low $\mathrm{pH}$ conditions.

The molecular weight of proteins in SD and SN fractions was calculated based on the patterns of gel filtration chromatography. Figure 7 shows semilogarithmic plots relating the distribution coefficients to the molecular weight of proteins of SD or SN fraction and several marker proteins. From this graph, molecular weight of protein in SD and SN fraction was calculated to be approximately 14,000 .

To make further examination of SD fraction the eluates corresponding to the major protein peaks, fraction Nos. 32 to 38, of the gel filtration pattern of SD fraction were subjected to rechromatography. In this rechromatographic pattern distinct single peak with no shoulder was found at the fraction number same as that of the original chromatogram. The fractions from Nos. 22 to 32, which corresponded to higher molecular weight, were also rechromatographed after an adequate incubation. In this case major part of the protein was eluted at the same 


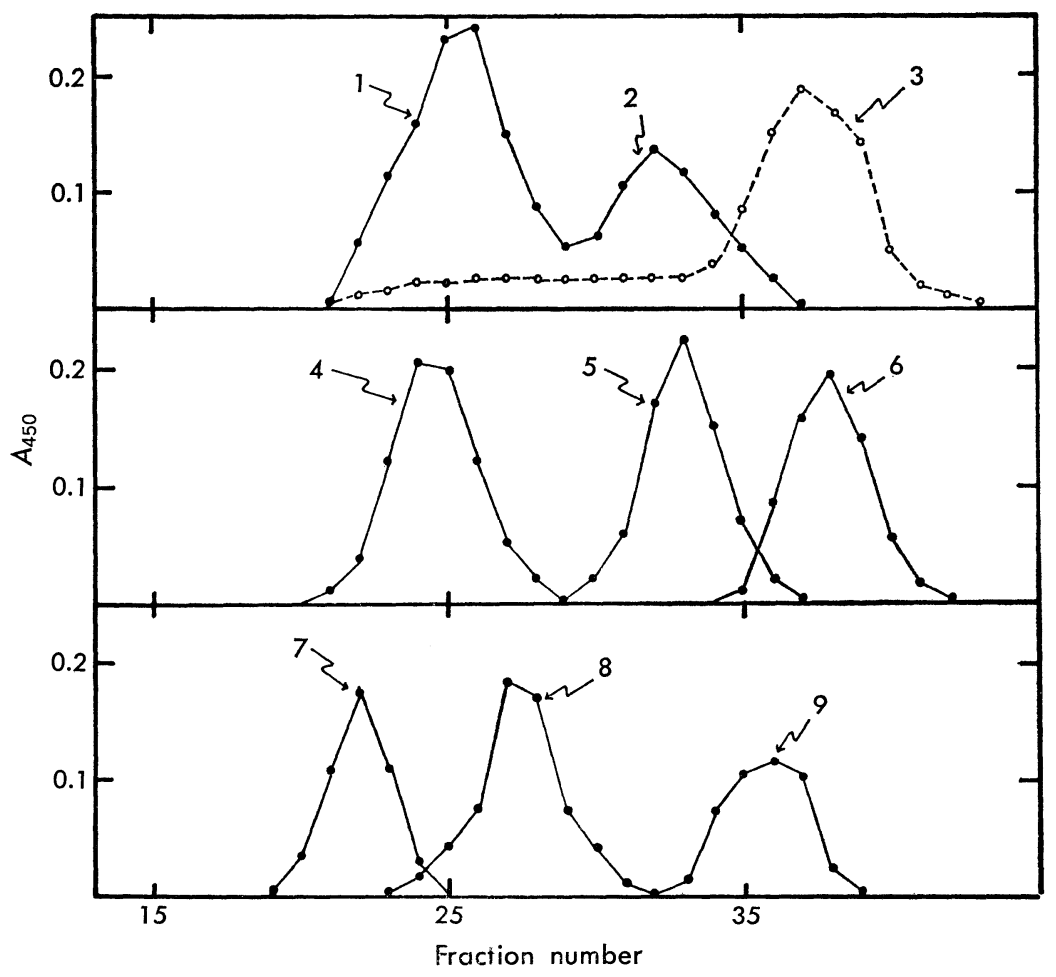

Fig. 4. Elution diagram of SD fraction and authentic proteins chromatographed over Sephadex G-200 in SDS-borate buffer (pH 12.0).

1, $\gamma$-globulin H-chain; 2, $\gamma$-globulin L-chain; 3, SD fraction; 4, albumin; 5, chymotrypsinogen; 6 , cytochrome $c ; 7$, Blue Dextran $\left(\mathrm{OD}_{750}\right) ; 8$, ovalbumin; 9, myoglobin.

position as that of the main peak of the original chromatogram. These results suggest that the major peak in the original chromatogram of SD fraction corresponded to the monomer protein (SD-m protein) which had a molecular weight of 14,000. Table 2 is a comparison of the amino acid composition of protein between protein in SD fraction and SD-m protein. The amino acid composition of SD-m protein was similar to that of protein in SD fraction. It was concluded that SD fraction consisted mainly of SD-m protein.

\section{Sedimentation velocity studies}

Ultracentrifugation pattern on a Spinco model $\mathrm{E}$ of components of SN fraction in $0.1 \%$ SDS and $0.05 \mathrm{~m}$ sodium borate buffer ( $\mathrm{pH} \mathrm{12.0)}$ showed that this fraction was heterogeneous but that SD fraction was homogeneous, with respect to the molecular weight (Fig. 8).

\section{Analysis of $\mathrm{NH}_{2}$-terminal residue}

Results of the $\mathrm{NH}_{2}$-terminal analysis of the spore coat preparation and SD 


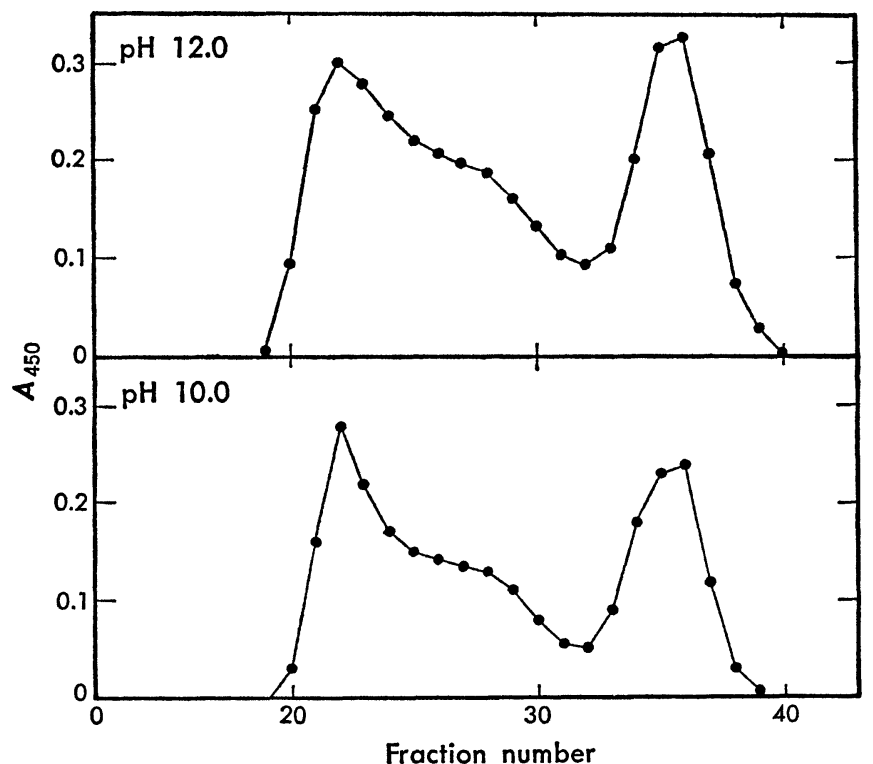

Fig. 5. Sephadex G-200 chromatogram of SN fraction in SDS borate buffer (pH 10.0 and $\mathrm{pH} 12.0)$.

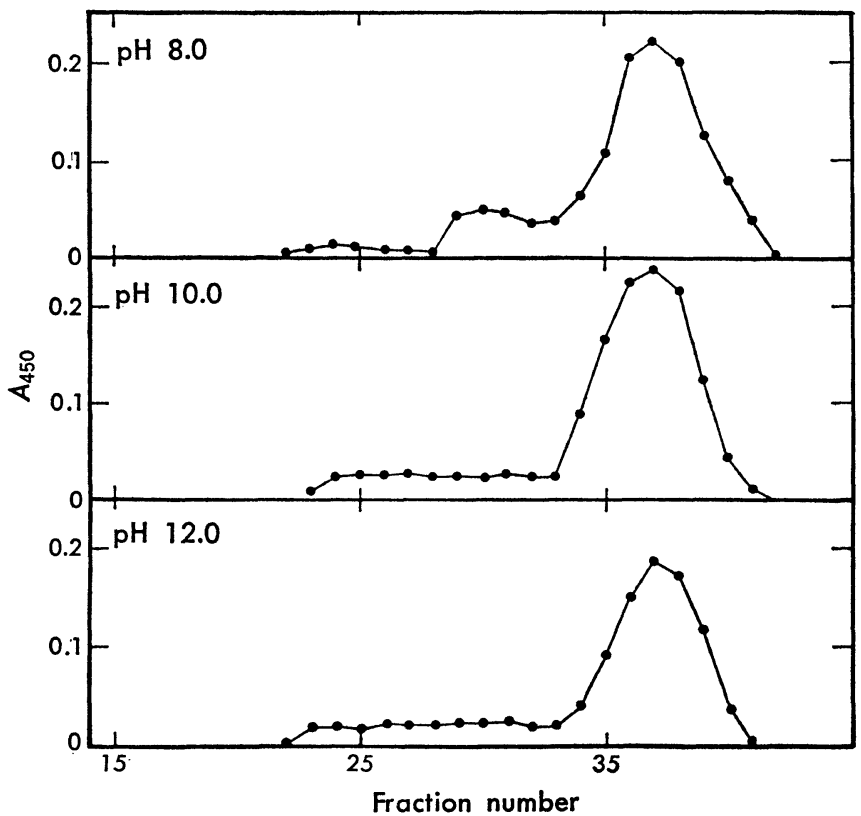

Fig. 6. Sephadex G-200 chromatogram of SD fraction in SDS borate buffer ( $\mathrm{pH} 10.0$ and $\mathrm{pH} 12.0)$ and SDS Tris- $\mathrm{HCl}$ buffer ( $\mathrm{pH} 8.0)$. 


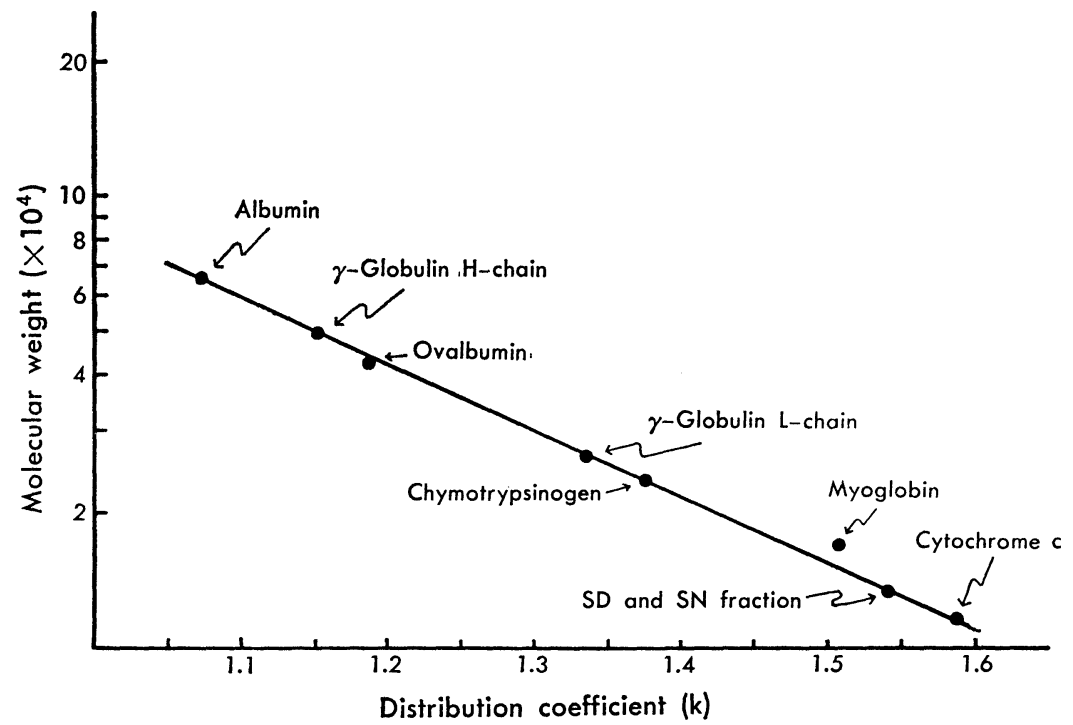

Fig. 7. Semilogarithmic plots relating the distribution coefficients (k) to the molecular weight of proteins in SD and SN fractions and marker proteins.

Table 2. Comparison of amino acid composition of SD fraction and SD-m fraction.

\begin{tabular}{lcc}
\hline \multicolumn{1}{c}{ Amino acid } & SD-m fraction & SD fraction \\
\hline Lysine & 6.5 & 6.1 \\
Histidine & 2.0 & 2.0 \\
Arginine & 4.9 & 8.0 \\
Aspartic acid & 14.0 & 12.2 \\
Threonine & 5.3 & 5.0 \\
Serine & 8.3 & 8.7 \\
Glutamic acid & 5.7 & 6.8 \\
Proline & + & 3.6 \\
Glycine & 14.0 & 14.3 \\
Alanine & 8.8 & 8.7 \\
Cystine (half) & + & 0.8 \\
Valine & 4.8 & 5.2 \\
Methionine & 1.4 & 1.7 \\
Isoleucine & 4.2 & 4.3 \\
Leucine & 5.9 & 5.6 \\
Tyrosine & 6.3 & 7.1 \\
Phenylalanine & 5.1 & 4.6 \\
\hline
\end{tabular}

Values are $\mathrm{mol} \%$.

fraction are illustrated in Figs. 9 and 10. Solvent systems used were toluene: pyridine: ethylenechlorohydrin: $0.8 \mathrm{~N} \mathrm{NH}_{4} \mathrm{OH}(100: 30: 60: 60, \mathrm{v} / \mathrm{v}$ ) and chloro- 


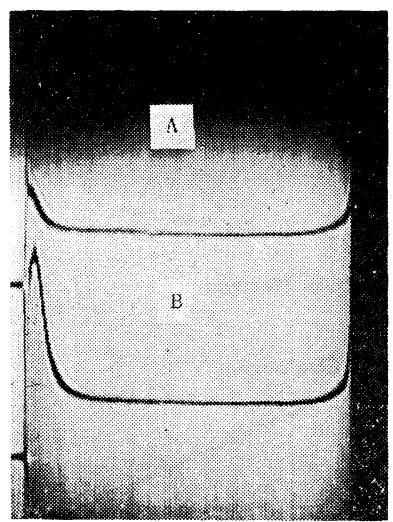

Fig. 8. Sedimentation pattern of SD fraction and SN fraction.

The fractions were dissolved in $0.1 \%$ SDS and 0.05 м sodium borate buffer ( $\mathrm{pH} 12.0$ ). The protein concentration was $10.0 \mathrm{mg} / \mathrm{ml}$. A, SN fraction; B, SD fraction.

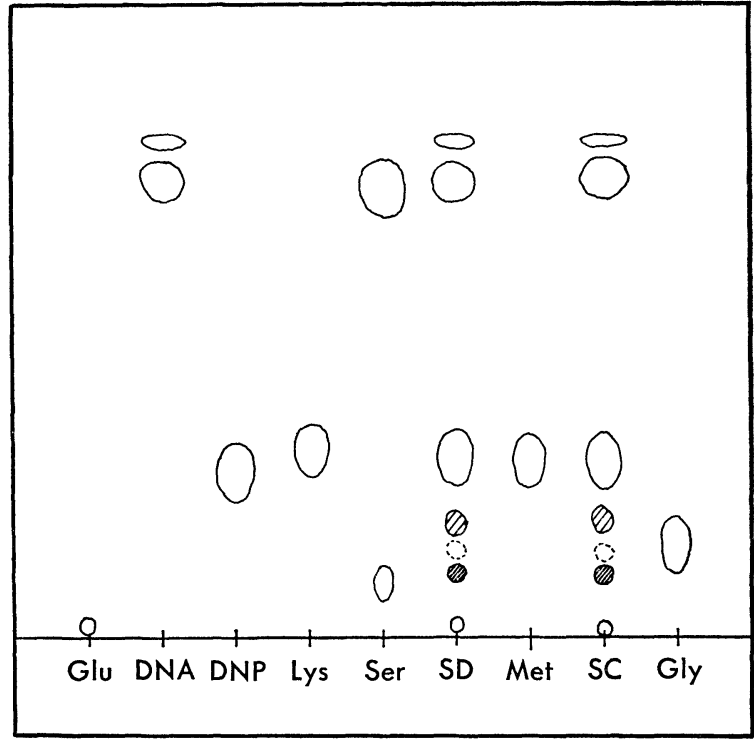

Fig. 9. $\mathrm{NH}_{2}$-terminal analysis of spore coat preparation and its solubilized fraction (SD fraction).

Solvent system used for chromatography was toluene-pyridine-ethylenechlorohydrin-0.8 $\mathrm{N} \mathrm{NH}_{4} \mathrm{OH}(100: 30: 60: 60, \mathrm{v} / \mathrm{v})$. SC, spore coat; SD, SD fraction. The shadowed circles indicate the spots which contain DNP-amino acids in a very high concentration.

form: methanol: acetic acid (95:5:1, v/v), respectively. Both $\mathrm{SD}$ and $\mathrm{SN}$ fractions showed a similar distribution pattern of DNP-amino acids. The 


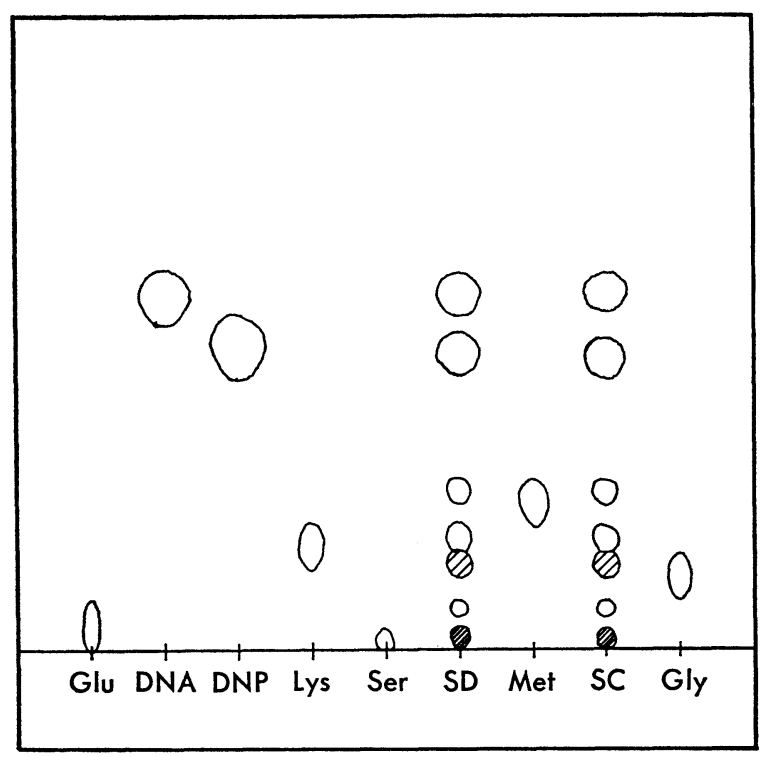

Fig. 10. $\mathrm{NH}_{2}$-terminal analysis of $\mathrm{SD}$ fraction.

Solvent system used was chloroform-methanol-acetic acid $(95: 5: 1, \mathrm{v} / \mathrm{v})$. The shadowed circles indicate the spots which contain DNP-amino acids in a very high concentration.

DNP-amino acid showing the highest concentration in the chromatograms was serine. Small amounts of methionine, glycine, glutamic acid, and lysine were found in the form of DNP-amino acid. These data suggest that most of the $\mathrm{NH}_{2}$ terminal amino acids in the spore coat protein of $B$. subtilis 6051 was serine.

\section{DISCUSSION}

Aronson and Horn (6) reported that the spore coat of $B$. cereus $\mathrm{T}$ contained protein whose molecular weight was 12,000 as the major component. They solubilized the intact spore by sequential treatments with DTE solution ( $\mathrm{pH} \mathrm{10.3)} \mathrm{and}$ DTE plus SDS solution. However, the solubilization percentage of the spore coat protein by these treatments was not made clear. Furthermore, these treatments may also solubilize a portion of the exosporium.

In the present work, we tried to solubilize the spore coat which had been isolated from the spore. In our case approximately $80 \%$ in dry weight of the spore coat was solubilized by the use of DTT and SDS solution. Analysis of the solubilized fraction in all the experiments was made in a buffer added with SDS. We have not observed morphologically which layer of the spore coat was solubilized by these treatments. However, it is interesting that the results obtained by our method were similar to those of ARONSON and HORn. This fact suggests that the 
spore coat protein was fairly homogeneous.

It was found that the spore coat protein was scarcely solubilized under physiological $\mathrm{pH}$ conditions. Similar results were reported by Gould et al. (2). We found that the spore coat protein was easily solubilized under alkaline conditions. This fact, together with the fact that the spore coat protein contained aspartic acid and glutamic acid in a high concentration, suggested that the spore coat protein was acidic. Strong alkaline solutions have been widely used to solubilize the spore coat protein but it seems that the denaturation occurring under extremely alkaline condition is more complicated than that by SDS (15). Furthermore, some chemical modifications occur under extremely alkaline condition. Our observations on behaviors of the spore coat protein in respect to electrophoresis, gel filtration, and sedimentation analysis also suggested that the spore coat protein aggregated by a treatment with strong alkali. Therefore, it is thought that the use of a strong alkali for further study of the spore coat protein is adequate.

The $\mathrm{NH}_{2}$-terminal analysis in the present study suggested that most of the $\mathrm{NH}_{2}$-terminal amino acids in the spore coat protein was serine. HIRAGI (16) reported different results with $B$. subtilis; he found that lysine, alanine, glycine, and serine were main $\mathrm{NH}_{2}$-terminal amino acids of the spore coat protein. The discrepancy between our result and Hiragi's may be due to the difference in the condition of the reaction with dinitrofluorobenzene or in the methods used for solubilization of the spore coat protein. In the case of $B$. cereus, glycine was reported to be the main $\mathrm{NH}_{2}$-terminal amino acid of soluble fraction of the spore coat protein.

The spore coat protein must be synthesized in the nascent form in the cells and assembled together on the surface of forespore during sporulation. KADOTA et al. (17) succeeded in the in vitro synthesis of spore proteins by using polyribosomes from sporulating nascent protein of spore coat from the products of their protein synthesis system. It will be interesting to assemble the nascent protein of spore coat during sporulation of bacilli.

\section{REFERENCES}

1) M. Kondo and J. W. Foster, J. Gen. Microbiol., 47, 257 (1967).

2) G. W. Gould, J. M. Stubb, and W. L. King, J. Gen. Microbiol., 60, 347 (1970).

3) A. I. Aronson and P. C. Fitz-James, J. Mol. Biol., 33, 199 (1968).

4) M. M. Lecadet, G. Chevrier, and R. Dedonder, Eur. J. Biochem., 25, 349 (1972).

5) H. J. Somerville, F. P. Delafieil, and S. C. Rittenberg, J. Bacteriol., 101, 551 (1970).

6) A. I. Aronson and D. Horn, In Spores V, ed. by H. O. Halvorson et al., American Society for Microbiology (1971), p. 19.

7) H. Kadota, K. Iujma, and A. Uchida, Agr. Biol. Chem. (Tokyo), 29, 870 (1965).

8) L. E. Sacks and G. Alderton, J. Bacteriol., 82, 331 (1961).

9) W. W. Fish, K. G. Mann, and C. TAnford, J. Biol. Chem., 244, 4989 (1969).

10) K. Weber and M. Osborn, J. Biol. Chem., 244, 4406 (1969).

11) D. H. Spackman, W. H. Stein, and S. Moore, Anal. Chem., 30, 1190 (1958). 
12) K. Horikoshi and R. H. DoI, J. Biol. Chem., 243, 2381 (1968).

13) A. Korngerg, J. Spudich, D. L. Nelson, and M. P. Deutscher, Annu. Rev. Biochem., 37, 51 (1968).

14) J. A. Spudich and A. Kornberg, J. Biol. Chem., 243, 4588 (1968).

15) C. Tanford, Adv. Protein Chem., 23, 121 (1968).

16) Y. Hiragi, J. Gen. Microbiol., 72, 87 (1972).

17) H. Kadota, A. Uchida, and T. Sakata, Proc. 45th Annu. Meet. Agr. Chem. Soc. Jpn., p.274 (1969), abstract in Japanese. 